\title{
Siew New Disease Reports \\ First report of wood canker of pomegranate caused by Cytospora punicae in western Iran
}

M. Mahdikhani ${ }^{1 *}$ and A. Davoodi ${ }^{2}$

\author{
${ }^{1}$ Agriculture Service Centre of Buin Zahra, Mofatteh St., Valiasr Sq., 34186-42615 Buin Zahra, Qazvin, Iran; ${ }^{2}$ Agricultural \\ and Natural Resources of Research and Education Centre of Qazvin, Helal Ahmar St., Modarres Sq., 34156-25641 Qazvin, \\ Iran
}

*E-mail: m.mahdikhani2016@gmail.com

Received: 30 Oct 2016. Published: 04 Jan 2017. Keywords: BLAST analysis, EF1- $\alpha$, ITS region, Punica granatum

Pomegranate (Punica granatum) is one of the most important crops in western Iran with an annual production of approximately 60,000 tonnes. During August and September 2015 a severe dieback was observed on branches and limbs of pomegranate cv. Atabaki, growing in orchards in Tarom, Qazvin province (approximately 30\% of trees in each orchard were infected). Cankers and yellowing of the foliage was also associated with the disease. At the canker site the bark was torn open, exposing dark-brown stained sapwood. A fungus was constantly isolated from the diseased tissues and plated onto potato dextrose agar (PDA) modified with tetracycline hydrochloride $(100 \mu \mathrm{g} / \mathrm{ml})$.

Representative isolates were sub-cultured onto PDA and incubated at $25^{\circ} \mathrm{C}$ under fluorescent light (12 $\mathrm{h}$ photoperiod). The colonies that developed were initially whitish, but turned green to dark brown with maturity. Darkbrown pycnidia $(\mathrm{n}=25)$ formed after 15 days, of which most were (260-)360-495(-590) $\mu \mathrm{m}$ in diameter. The conidia were allantoid, aseptate, hyaline, ranging from (4-)4.5-5.4(-6) $\mu \mathrm{m}$ long $\times(1.5-) 2(-2.5) \mu \mathrm{m}$ wide $(\mathrm{n}=80)$. Based on these morphological characteristics the fungus was identified as Cytospora punicae. To confirm the morphological identification the primer pair ITS1/ITS4 (ITS region) of rDNA and part of the translation elongation factor 1-alpha gene $(E F 1-\alpha)$ were used for amplification and sequencing. The sequences obtained (GenBank Accession Nos. KY049839 and KY049842) showed 99\% homology with isolates of C. punicae (KJ621684, KJ621687, KJ621688, KR020716 and KR020717).

In November 2015, pathogenicity tests were performed using one of the $C$ punicae isolates. Branches of two-year-old trees of $P$. granatum cv. Atabaki were selected and a wound made by lifting the bark with a cork borer. The fresh wound was inoculated with a mycelial agar plug $(5 \mathrm{~mm}$ in diameter taken from the edge of a PDA culture. Five branches each from different trees were inoculated per isolate. The controls consisted of five branches inoculated with only plugs of sterile PDA. In order to maintain humidity, inoculations were coated with paraffin film and wrapped with petroleum jelly. In August 2016, all branches were assessed for canker development and the extent of vascular discoloration spreading from the inoculation point. Those branches that were inoculated with $C$. punicae had developed cankers with an average length of $22 \mathrm{~cm}$ (length of vascular discoloration). To fulfill Koch's postulates, isolations were made from the margins of the discolored tissues. The pathogen was reisolated from all of the branches and discoloured tissues inoculated with the fungus.

Cytospora punicae has been previously described as a stem, twig and branch pathogen causing dieback and cankers on pomegranate trees in a number of countries (Palou et al., 2013; Peduto Hand et al., 2014; Samouel \& Kanetis, 2016). To our knowledge, this is the first report of $C$. punicae causing cankers and branch dieback of pomegranate in Iran.

\section{References}

Palou L, Taberner V, Guardado A, Del Rio MA, Montesinos-Herrero C, 2013. Incidence and etiology of postharvest fungal diseases of pomegranate (Punica granatum cv. Mollar de Elche) in Spain. Phytopathologia Mediterranea 52, 478-489.

http://dx.doi.org/10.14601/Phytopathol_Mediterr-11581

Peduto Hand F, Choudhury RA, Gubler WD, 2014. First report of Cytospora punicae causing wood canker and branch dieback of pomegranate (Punica granatum) in the United States. Plant Disease 98, 853. http://dx.doi.org/10.1094/PDIS-11-13-1133-PDN

Samouel S, Kanetis L, 2016. First report of Cytospora punicae causing trunk canker of pomegranate (Punica granatum) in Cyprus. Plant Disease 100, 222. http://dx.doi.org/10.1094/PDIS-03-15-0356-PDN

To cite this report: Mahdikhani M, Davoodi A, 2017. First report of wood canker of pomegranate caused by Cytospora punicae in western Iran. New Disease Reports 35, 1. http://dx.doi.org/10.5197/j.2044-0588.2017.035.001

(c) 2017 The Authors This report was published on-line at www.ndrs.org.uk where high quality versions of the figures can be found. 